\title{
Static Liquid Culture of Doritaenopsis Seedlings
}

\author{
Wei-Ting Tsai and Chien-Young $\mathrm{Chu}^{1}$ \\ Department of Horticulture, National Chung Hsing University, 250 Kuo \\ Kuang Road, Taichung 402, Taiwan
}

Additional index words. Phalaenopsis, sowing density, support, hyperhydricity, vitrification

\begin{abstract}
Methods for static liquid culture are described to improve the growth of Doritaenopsis (commercially known as Phalaenopsis) seedlings in vitro. The results showed that seeds not only germinated, but also grew faster in liquid medium. No hyperhydric seedlings were observed in liquid culture when liquid level was accurately controlled by culture density, medium volume, and sealing materials. Although the germination percent was unaffected by medium phase (liquid or solid), sowing density, medium volume, or sealing material, the growth of seedlings decreased as density increased or medium volume decreased. Seeds of $1.5 \mathrm{mg}$ mixed with $20 \mathrm{~mL}$ of liquid medium per 9-cm petri dish sealed with two layers of parafilm prompted optimal results. Shoot growth also was enhanced while 75-day-old seedlings were subcultured in liquid media with or without support. Seedling growth was enhanced by adding $20 \mathrm{~mL}$ liquid media to 36 seedlings without support after 45 days of culture. It was expected that by static liquid culture, the period from sowing to ex vitro would be 1.5 months shorter than the traditional solid culture.
\end{abstract}

Phalaenopsis and Doritaenopsis, hybrids between Phalaenopsis and Doritis, are collectively referred to as Phalaenopsis, the major floral crop in Taiwan for exporting. Asymbiotic culture on an agar-solidified medium is the main method for mass production. However, the high price of agar and the amount of time needed for preparing the medium result in increasing costs. Moreover, plantlets do not grow uniformly on solid medium and require added labor for grouping before subculture.

Seeds of epiphytic orchids, including Phalaenopsis, can germinate on a specific host tree in nature. However, the bark surface of the host tree plays an important role in determining whether seeds can germinate on it. Soft, spongy, water-filled bark with an uneven surface is more suitable than a smooth surface (Arditti, 1992). In addition, epiphytic orchids may also rely on mycorrhizal fungi (mycotrophy) as an additional surface of water (Yoder et al., 2000). In our laboratory, Doritaenopsis seeds germinated on the walls of the vessel where nutrient liquid remained and seeds germinated faster than those on a solid medium.

Given that in vitro liquid culture has been used successfully to cultivate a number of important nonorchids such as rhododendron (Douglas, 1984), conifers (Pâques et al., 1992), roses (Wong and Chu, 1995), and

\footnotetext{
Received for publication 23 Mar. 2007. Accepted for publication 25 July 2007.

The funding for this study was provided by the Council of Agriculture, Taiwan (91AS-3.1.3-FDZ1-3).

We thank Yin-Tung Wang for critical review and suggestion on the manuscript.

${ }^{1}$ To whom reprint requests should be addressed; e-mail chychu@dragon.nchu.edu.tw
}

garlic (Kim et al., 2003), we explored the possibility that orchids, namely Doritaenopsis, could be cultured in this manner with optimal results. However, hyperhydricity (or vitrification) was a serious problem in longterm liquid culture (Etienne and Berthouly, 2002; Ziv, 1994). The hyperhydric materials were unable to grow into normal plants, and it was hard to recover to a normal state (Zhou, 1995). In this study, we investigated raising normal Doritaenopsis seedlings from seeds in a static liquid medium.

\section{Materials and Methods}

\section{Materials}

Capsules of Doritaenopsis [(Dtps. Tinny Antique $\times$ Dtps. Sinica Peeress $) \times D t p s$. Sogo Beach] were harvested 4.5 months after artificial hand-pollination. Capsules were surface-sterilized for 10 min with $2 \%$ sodium hypochlorite and then rinsed three times with sterilized deionized water. Seeds were collected and weighed under aseptic condition. Seeds were stained for $24 \mathrm{~h}$ with $0.5 \%$ triphenyl tetrazolium chloride at $25^{\circ} \mathrm{C}$; seeds over $90 \%$ viability were used. The stock suspension was prepared by mixing $150 \mathrm{mg}$ seeds and $100 \mathrm{~mL}$ autoclaved sowing medium containing Knudson C (Knudson, 1946) inorganic salts, $20 \mathrm{~g} \cdot \mathrm{L}^{-1}$ sucrose, and $34 \mathrm{~g} \cdot \mathrm{L}^{-1}$ potato paste. There were $500 \pm 50$ seeds per milligram.

Initial culture. Sterile, disposable, 9-cm plastic petri dishes (Alpha Plus Scientific Corp., Taoyuan, Taiwan) were used for liquid sowing, and, without stating otherwise, dishes were sealed with two layers of parafilm (American National Can Co., Menasha, WI). For the control, $1 \mathrm{~mL}$ of stock suspension was spread over $80 \mathrm{~mL}$ of solid medium containing $8 \mathrm{~g} \cdot \mathrm{L}^{-1}$ agar in a $500-\mathrm{mL}$ flask.
The flask was capped with a rubber stopper, which was $3 \mathrm{~cm}$ in height and had a $7.5-\mathrm{mm}$ hole that was plugged with $0.1 \mathrm{~g}$ dried cotton. The juncture of the stopper and flask was sealed with six layers of parafilm.

Two weeks after sowing, germinated seeds were identified by enlarged embryos that had burst out of the testa. Two hundred seeds in each petri dish/flask were randomly chosen to determine the germination percent.

\section{Effect of sowing density on the growth} of seedling

To 1,2 , or $3 \mathrm{~mL}$ of stock seed suspension, 9,8 , or $7 \mathrm{~mL}$ of sowing medium was added, respectively. Thus, the total amount of medium was $10 \mathrm{~mL}$ in each petri dish and the amount of seed was $1.5,3.0$, or $4.5 \mathrm{mg}$ per petri dish, respectively. The petri dish was sealed by two layers of parafilm. The diameters of 50 random seedlings were measured weekly from each dish under a stereo microscope (Nikon SMZ-10, Tokyo) for 5 weeks.

\section{Anatomical observations}

Fresh seedlings in liquid (sown as $1.5 \mathrm{mg}$ seed per petri dish) or on solid medium $35 \mathrm{~d}$ after sowing were used for anatomical observations by cryosectioning without fixation and staining. Seedlings were put on a stainless steel plate and mounted with watersoluble Tissue Freezing Medium (Leica Instruments $\mathrm{GmbH}$, Heidelberg, Germany), and then put into Cryocut 1800 (Leica Instruments $\mathrm{GmbH}$ ), which was precooled to $-15{ }^{\circ} \mathrm{C}$ to solidify the medium. A section of $45 \mu \mathrm{m}$ was cut and transferred to a microslide. A few drops of reverse osmosis water was added to dissolve the medium at ambient temperature, and the tissue section was observed under a light microscope.

Effect of liquid medium volume on seedling growth. The stock seed suspension of $1 \mathrm{~mL}$ was added to $4,9,14,19$, or $24 \mathrm{~mL}$ of sowing medium. Thus, with a common amount of $1.5 \mathrm{mg}$ seeds per petri dish, the total amount of medium was 5, 10, 15, 20, or $25 \mathrm{~mL}$, respectively. Three months after sowing, the growth of seedlings was investigated. A total of 150 seedlings in each dish/ flask was randomly selected and separated into three groups. Seedlings in each group were classified into three growth stages: stage I: heart-shaped to torpedo-shaped embryo; stage II: first leaf $3 \mathrm{~mm}$ or less; and stage III: first leaf greater than $3 \mathrm{~mm}$. The fresh weight of seedlings were recorded; also, dry weight was determined after drying in an oven at $60{ }^{\circ} \mathrm{C}$ for $48 \mathrm{~h}$.

Effect of liquid medium volume and sealing material on seedling growth. One milliliter stock seed suspension was diluted to 10 or $20 \mathrm{~mL}$ of sowing medium. Then the petri dishes were sealed by two layers of parafilm or micropore tape (Micropore surgical tape; 3M Co., St. Paul, MN). The diameters of 50 randomly selected seedlings in each petri dish were recorded weekly for 8 weeks. The average rate of evaporational water loss from the petri dishes sealed with 
the two types of materials was presented as the weight loss per day.

Subculture. After sowing in liquid medium for $75 \mathrm{~d}$, seedlings with a 1- to 2$\mathrm{mm}$ leaf length were selected for subculture. In the subculture medium, the inorganic salts were replaced by one-fourth strength of MS (Murashige and Skoog, 1962) as well as replacing the petri dish with GA-7 vessel (length $\times$ width $\times$ height $=77 \times 77 \times 97 \mathrm{~mm}^{3}$ ) (Magenta Co., Chicago). In parts of the liquid culture, support of microporous membrane raft (Magenta Co.) (LR) or four layers of $5 \times$ $5 \mathrm{~cm}^{2}$ nonwoven fabrics (length $\times$ width $\times$ height $=5 \times 5 \times 1 \mathrm{~cm}^{3}, 143.52 \mathrm{~g} \cdot \mathrm{m}^{-2}$; Shin-Li Co., Banchiau, Taiwan) covered with one layer of paper towel $\left(5 \times 5 \mathrm{~cm}^{2}\right.$; Kleenex; Kimberly-Clark Co., Taipei, Taiwan) (LN) was placed in the vessel. There was also solid medium in flasks as control. The flasks were capped with rubber stoppers as described previously. The growth of seedlings was investigated 45 and $75 \mathrm{~d}$ after subculture. The fresh weight of seedlings was recorded after $75 \mathrm{~d}$ of subculture and the dry weight was determined after drying in an oven at $60{ }^{\circ} \mathrm{C}$ for $48 \mathrm{~h}$.

Pretransplanting. After $45 \mathrm{~d}$ of subculture, seedlings from the control and the best liquid culture during subculture ( $\mathrm{S}$ and $\mathrm{LO}_{20}^{36}$ in Table 2) were randomly chosen and transferred to a $650-\mathrm{mL}$ flask containing $120 \mathrm{~mL}$ of solidified pretransplanting medium containing $3 \mathrm{~g} \cdot \mathrm{L}^{-1}$ Hyponex No. 1 , $2 \mathrm{~g} \cdot \mathrm{L}^{-1}$ tryptone, $0.1 \mathrm{~g} \cdot \mathrm{L}^{-1}$ citric acid, $90 \mathrm{~g} \cdot \mathrm{L}^{-1}$ banana, and $15 \mathrm{~g} \cdot \mathrm{L}^{-1}$ sucrose for rooting. Twenty-five seedlings were transplanted to each flask. The flasks were capped with a rubber stopper as described previously. The number of leaf and root and length of the longest leaf and root of each plant were recorded after $120 \mathrm{~d}$ of culture.

\section{Culture condition}

Temperature in the culture room was maintained at $24 \pm 2{ }^{\circ} \mathrm{C}$. Photosynthetic photon flux at $35 \pm 5 \mu \mathrm{mol} \cdot \mathrm{m}^{-2} \cdot \mathrm{s}^{-1}$ for a $12-\mathrm{h}$ photoperiod was supplied by a cool white fluorescent lamp (FL40D/38; China Electric Mfg. Co., Taipei, Taiwan).

\section{Statistical analysis}

The experiments were conducted in a complete randomized design and there were three replications in each treatment. The average values were analyzed by Costat (CoHort Software, Minneapolis, MN), and the differences were compared by analysis of variance and Duncan's multiple range test at $P \leq 0.05$.

\section{Results}

Two weeks after sowing, the germination percent ranged from $89.8 \%$ to $94.3 \%$. It was not significantly affected by the types of medium or sowing density. However, seeds sown on solid medium germinated slower than those in liquid medium (Fig. 1). The growth of seedlings in liquid medium significantly decreased as sowing density in-

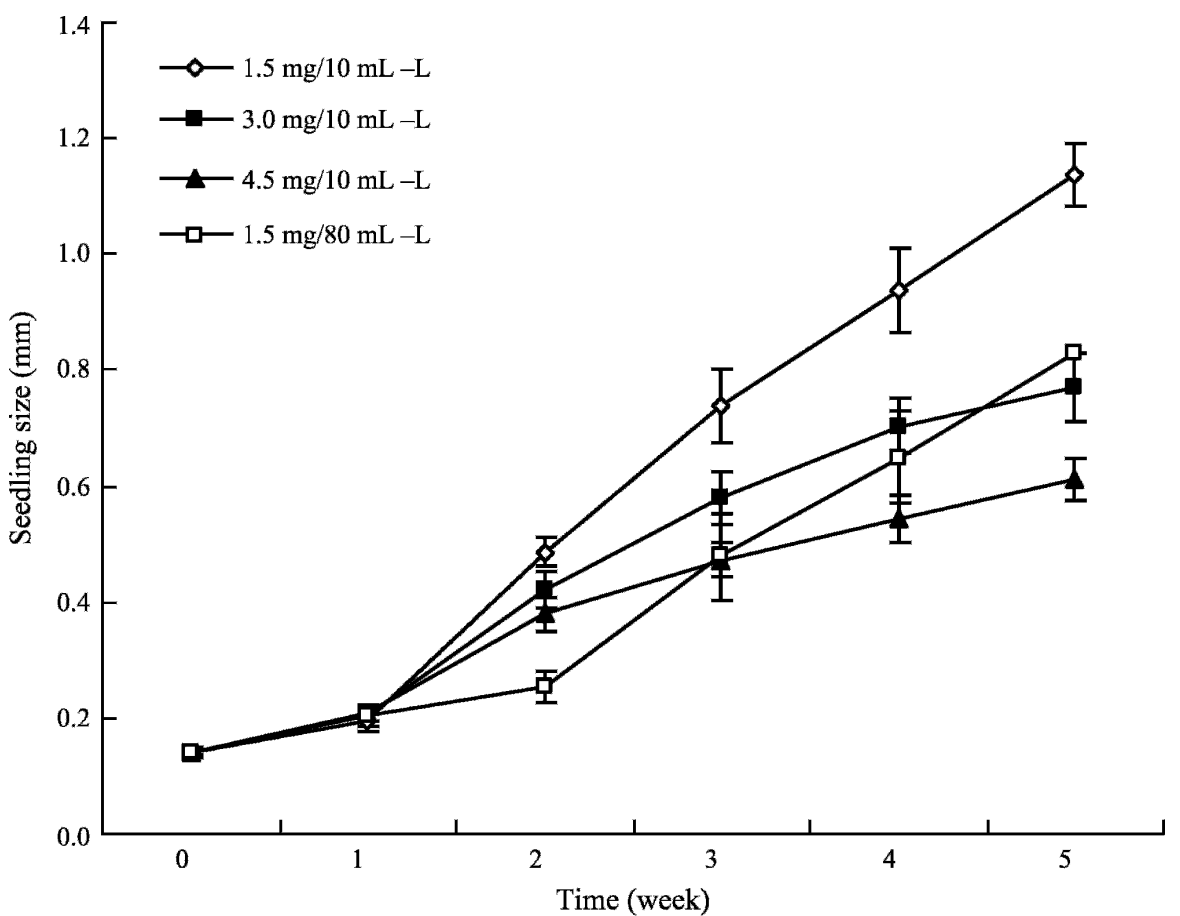

Fig. 1. Effect of sowing density on seedling growth. L and S represent liquid and solid medium, respectively. The bars present SEs, $\mathrm{n}=50$.

Table 1. Effects of liquid medium volume on the growth of seedlings 3 months after sowing.

\begin{tabular}{|c|c|c|c|c|c|c|c|c|}
\hline \multirow[b]{2}{*}{$\begin{array}{l}\text { Medium } \\
\text { volume }(\mathrm{mL})\end{array}$} & \multirow[b]{2}{*}{$\begin{array}{c}\text { Germination } \\
(\%)\end{array}$} & \multirow[b]{2}{*}{$\begin{array}{c}\text { Mortality } \\
(\%)\end{array}$} & \multicolumn{3}{|c|}{ Seedling stage } & \multicolumn{3}{|c|}{ Wt. of 50 seedlings } \\
\hline & & & $\begin{array}{c}\text { Stage } I^{\mathrm{z}} \\
(\%)\end{array}$ & $\begin{array}{c}\text { Stage II } \\
(\%)\end{array}$ & $\begin{array}{c}\text { Stage III } \\
(\%)\end{array}$ & $\begin{array}{l}\text { FW } \\
(\mathrm{mg})\end{array}$ & $\begin{array}{l}\text { DW } \\
(\mathrm{mg})\end{array}$ & $\begin{array}{c}\mathrm{DW} / \mathrm{FW} \\
(\%)\end{array}$ \\
\hline 5 & $89.8 \mathrm{a}^{\mathrm{y}}$ & $0.7 \mathrm{~b}$ & $29.3 \mathrm{a}$ & $70.0 \mathrm{~cd}$ & $0 \mathrm{~d}$ & 82 e & $3.2 \mathrm{~d}$ & $3.9 \mathrm{c}$ \\
\hline 10 & $92.8 \mathrm{a}$ & $2.3 \mathrm{a}$ & $11.7 \mathrm{~b}$ & $78.3 \mathrm{bc}$ & $7.7 \mathrm{ab}$ & $243 \mathrm{c}$ & $10.2 \mathrm{c}$ & $4.2 \mathrm{bc}$ \\
\hline 15 & $91.7 \mathrm{a}$ & $2.3 \mathrm{a}$ & $6.3 \mathrm{bc}$ & $84.7 \mathrm{~b}$ & $6.7 \mathrm{~b}$ & $543 \mathrm{~b}$ & $22.9 \mathrm{a}$ & $4.2 \mathrm{bc}$ \\
\hline 20 & $94.3 \mathrm{a}$ & $1.7 \mathrm{a}$ & $0 \mathrm{c}$ & $95.0 \mathrm{a}$ & $3.3 \mathrm{c}$ & $575 \mathrm{ab}$ & $25.2 \mathrm{a}$ & $4.4 \mathrm{~b}$ \\
\hline 25 & $93.2 \mathrm{a}$ & $2.3 \mathrm{a}$ & $1.0 \mathrm{c}$ & $87.7 \mathrm{ab}$ & $9.0 \mathrm{a}$ & $623 \mathrm{a}$ & $23.9 \mathrm{a}$ & $3.8 \mathrm{c}$ \\
\hline $\mathrm{S}^{\mathrm{x}}$ & $93.0 \mathrm{a}$ & $0.7 \mathrm{~b}$ & $25.3 \mathrm{a}$ & $63.3 \mathrm{~d}$ & $10.7 \mathrm{a}$ & $189 \mathrm{~d}$ & $12.8 \mathrm{~b}$ & $6.7 \mathrm{a}$ \\
\hline
\end{tabular}

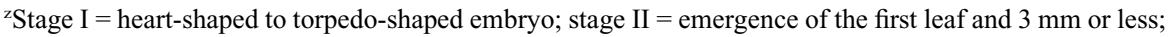
stage III = the first leaf greater than $3 \mathrm{~mm}$.

y Different letters within a column represent significant differences at $P \leq 0.05$ by Duncan's multiple range test. ${ }^{x}$ Eighty milliliters solid medium per flask.

Table 2. Effects of medium phase and support on the growth of seedlings after $45 \mathrm{~d}$ of subculture.

\begin{tabular}{|c|c|c|c|c|c|c|c|}
\hline & \multicolumn{3}{|c|}{ Seedling growth $(\%)$} & \multicolumn{2}{|c|}{ Leaf length (mm) } & \multicolumn{2}{|c|}{ Root } \\
\hline & 0 leaf & 1 leaf & 2 leaves & First & Second & Number & Length $(\mathrm{mm})$ \\
\hline$\overline{S_{100}^{90}}$ & $23.0 \mathrm{a}^{\mathrm{y}}$ & $75.0 \mathrm{~b}$ & $2.0 \mathrm{c}$ & $2.5 \mathrm{~d}$ & $1.0 \mathrm{c}$ & $0.43 \mathrm{~b}$ & $3.3 \mathrm{~b}$ \\
\hline $\mathrm{LO}_{20}^{36}$ & $2.5 \mathrm{c}$ & $12.5 \mathrm{c}$ & $85.0 \mathrm{a}$ & $4.6 \mathrm{bc}$ & $3.3 \mathrm{a}$ & $0.43 \mathrm{~b}$ & $3.9 \mathrm{ab}$ \\
\hline $\mathrm{LO}_{40}^{72}$ & $7.5 \mathrm{~b}$ & $16.3 \mathrm{c}$ & $76.2 \mathrm{a}$ & $5.4 \mathrm{a}$ & $3.1 \mathrm{a}$ & $0.43 \mathrm{~b}$ & $2.8 \mathrm{~b}$ \\
\hline $\mathrm{LR}_{50}^{36}$ & $0 \mathrm{c}$ & $72.2 \mathrm{~b}$ & $27.8 \mathrm{~b}$ & $4.4 \mathrm{c}$ & $2.4 \mathrm{~b}$ & $0.45 \mathrm{~b}$ & $5.1 \mathrm{a}$ \\
\hline $\mathrm{LN}_{40}^{36}$ & $0 \mathrm{c}$ & $97.2 \mathrm{a}$ & $2.8 \mathrm{c}$ & $5.1 \mathrm{ab}$ & $2.7 \mathrm{~b}$ & $0.75 \mathrm{a}$ & $4.1 \mathrm{ab}$ \\
\hline
\end{tabular}

${ }^{z}$ Medium phase $\mathrm{S}=$ solid; $\mathrm{L}=$ liquid; support $\mathrm{O}=$ without support; $\mathrm{R}=$ raft; $\mathrm{N}=$ nonwoven fabric covered with paper towel. Superscript $=$ no. of seedlings per vessel; subscript $=$ medium volume.

${ }^{y}$ Different letters within a column represent significant difference at $P \leq 0.05$ by Duncan's multiple range test.

creased. The growth curve of seedlings on solid culture was parallel to that of liquid culture 2 weeks after sowing at a density of $1.5 \mathrm{mg}$ per vessel, but the seedling diameter of the former was much smaller than the latter (Fig. 1).

The growth and fresh weight of seedlings increased as the volume of liquid medium increased from 5 to $25 \mathrm{~mL}$, and no treatment exsiccated during the 3 months of culture.
However, there was no difference in dry matter when medium volume exceeded 15 $\mathrm{mL}$. The most uniform growth of seedlings was in the $20-\mathrm{mL}$ treatment as $95 \%$ seedlings developed into stage II. Also, in this treatment, seedling fresh and dry weight was three and two times, respectively, of that in solid culture (Table 1).

Anatomical observation by cryosection showed that two kinds of cells - the condensed 
small cells at the anterior and the swollen cells at the posterior - were observed in seedlings from either liquid or solid culture $35 \mathrm{~d}$ after sowing (Fig. 2). Differentiation of the first leaf, second leaf, and rhizoid was observed in both seedlings. Root initiation was observed in the seedling from liquid culture only.

When dishes were sealed with Micropore tape, the evaporational water loss rate was $420 \mathrm{mg} \cdot \mathrm{d}^{-1}$. The medium dried up and seedlings stopped growing after 3 or 6 weeks when 10 or $20 \mathrm{~mL}$ medium was supplied, respectively (Fig. 3). When sealed with parafilm, water loss was reduced to 14.8 $\mathrm{mg} \cdot \mathrm{d}^{-1}$, and seedlings were of similar sizes after 6 weeks regardless of 10 or $20 \mathrm{~mL}$ medium was used. However, the growth slowed down after 6 weeks when only 10 $\mathrm{mL}$ medium was supplied. The growth rates were similar. The largest seedlings after 6 weeks were those in $20 \mathrm{~mL}$ of medium and sealed with parafilm.

Leaf number and length were enhanced by liquid culture whether or not a support was used (Table 2). Furthermore, most ( $76 \%$ to $85 \%$ ) seedlings cultured in liquid medium without support $\left(\mathrm{LO}_{20}^{36}\right.$ or $\mathrm{LO}_{40}^{72}$ ) developed two leaves, but $28 \%$ or fewer seedlings developed the second leaf in liquid culture with support (LR or LN). In addition, the leaf length in $\mathrm{LO}_{20}^{36}$ and $\mathrm{LO}_{40}^{72}$ was longer than in LR and LN. Seedlings that grew on nonwoven cloth (LN) had the most roots (Table 2).

After $75 \mathrm{~d}$, only seedlings in liquid culture without support $\left(\mathrm{LO}_{20}^{36}\right.$ and $\mathrm{LO}_{40}^{72}$ ) developed the third leaf. Seedlings in $\mathrm{LO}_{20}^{36}$ treatment had the most leaves and largest

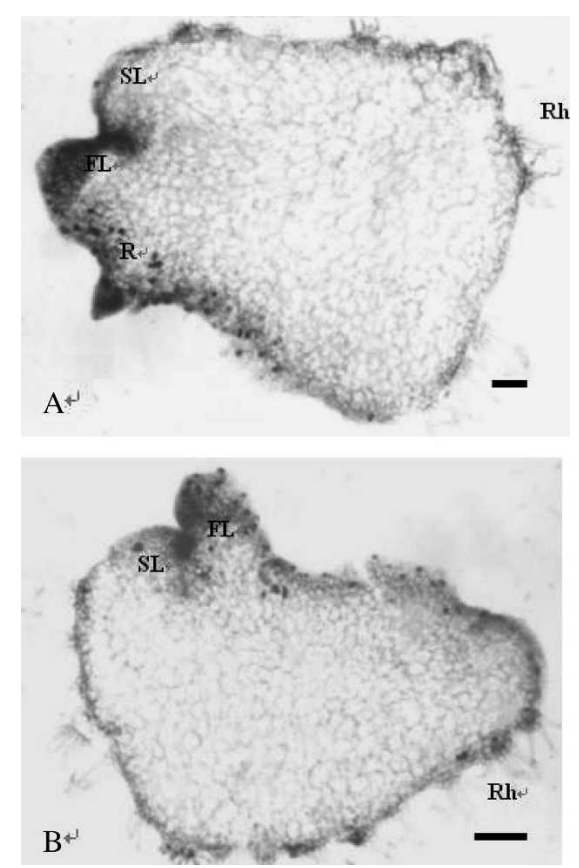

Fig. 2. Longitudinal sections of seedlings $35 \mathrm{~d}$ after sowing. The first leaf (FL), second leaf (SL) and rhizoids (Rh) differentiated from seedlings in liquid medium (A) or solid medium (B). Root (R) was evident on seedling from liquid culture. $\mathrm{Bar}=0.1 \mathrm{~mm}$. plant fresh and dry weight. Plants in liquid culture with supports (LR and LN) had similar root length. Fresh weight and dry weight of $\mathrm{LO}_{20}^{36}$ were 3.3 or 7.8 times that of solid culture (S), respectively. Although seedlings in $\mathrm{LO}_{40}^{72}$ developed the third leaf, their leaves were much shorter than those in $\mathrm{LO}_{20}^{36}$ and their roots were the shortest and turned brown after $75 \mathrm{~d}$ of subculture (Table 3).

After subculturing, the seedlings cultured in $\mathrm{LO}_{20}^{36}$ or on solid medium for $45 \mathrm{~d}$ to the solidified pretransplanting medium, the difference of growth between the two seedling sources increased as time progressed (Fig. 4). There were no differences detected in root number and the longest root length between seedlings from $\mathrm{S}$ and liquid culture without support $\left(\mathrm{LO}_{20}^{36}\right)$. However, the latter had more and longer leaves (Table 4).

\section{Discussion}

It had been reported that seeds of both epiphytic and terrestrial orchids had higher water content and germinated faster in symbiotic culture than that cultured asymbiotically on agar-solidified medium, because mycorrhizal fungi may facilitate the absorption of free water to enhance seed germination (Yoder et al., 2000). It was suggested that the delay of germination in asymbiotic sowing was induced by the lack of rapid increase of water acquisition (Yoder et al., 2000). This was supported by our results that Doritaenopsis seeds in liquid medium germinated faster than that on solid medium within 2 weeks (Fig. 1). However, germination percents were not different between the liquid and solid media.

The epidermal cells of Phalaenopsis protocorm are capable of absorbing nutrients
(Lee, 1990). Although the volume of the liquid medium was much less than the solid culture in this study, seedlings in liquid culture had greater fresh and dry weight (Fig. 1; Table 1), indicating that the growth of seedlings may be enhanced by increasing the surface of seeds in contact with free liquid. Orchid embryos form protocorms on germination, which accumulate carbohydrates and serve as a storage organ for seedling growth (Edwin, 1993). In our study, although the growth of seedlings stopped as the liquid medium dried, there was no significant change in seedling size (Fig. 3) and no dehydrated seedlings were observed during the drying period. Perhaps the nutrients and water stored in protocorms made it possible for seedlings to survive during the drying period for as long as 5 weeks.

Damaged meristem had been indicated as a typical characteristic of hyperhydric status and the promeristem zone comprising central mother cells had been reported absent in hyperhydric buds (Pâques and Boxus, 1987). It was reported that mature seeds of Phalaenopsis are composed of two kinds of cells: the small cells at the upper region and the big cells at the bottom (Edwin, 1993). The former differentiate into meristem and the latter serve as a storage organ, which is exhausted $30 \mathrm{~d}$ after sowing (Lee, 1990). Thus, it was inferred that the critical period for normal growth of seedlings was the stage of meristem differentiation after $\approx 30 \mathrm{~d}$ of sowing. In this study, normal meristem differentiation was observed in both liquid and solid culture $35 \mathrm{~d}$ after sowing (Fig. 2), indicating that normal meristem development was not hampered by liquid culture. Although the dry/fresh weight ratio of seedlings in liquid culture was lower than that on solid medium, leaves developed normally after

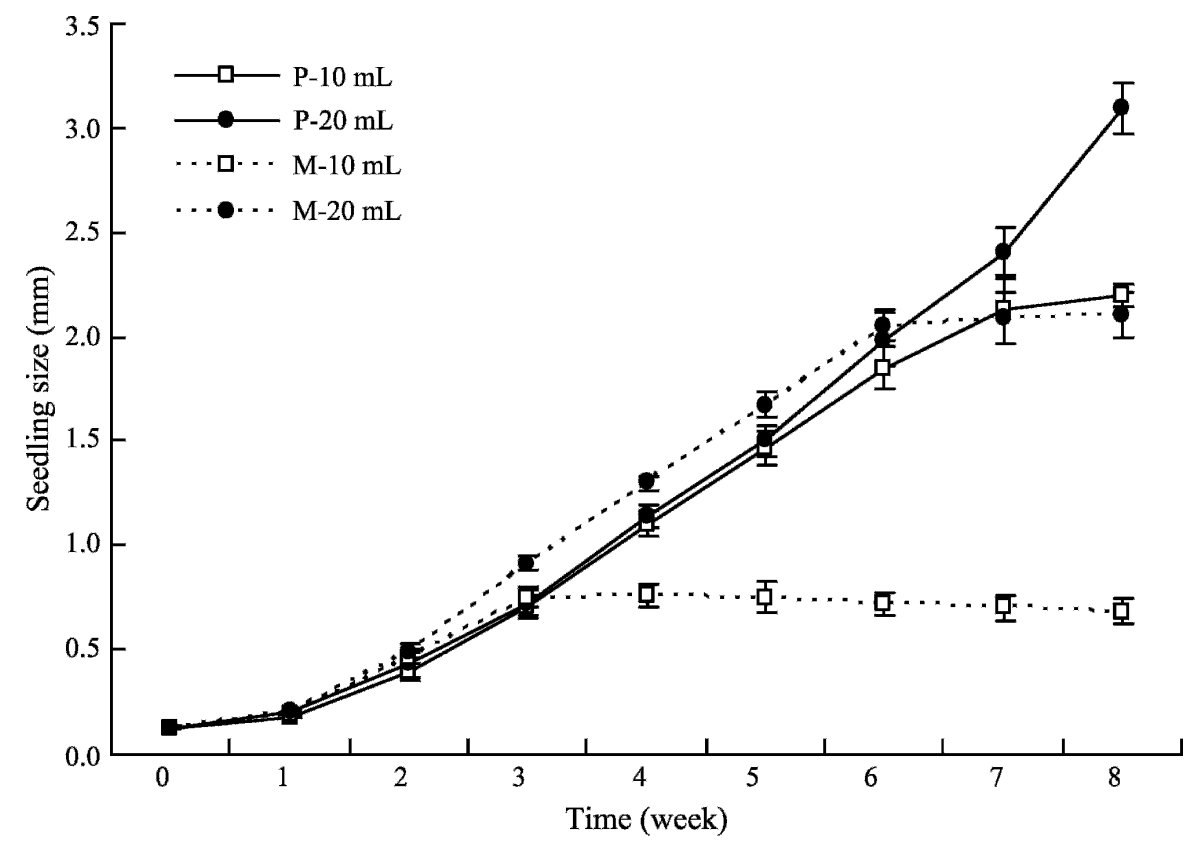

Fig. 3. Effect of medium volume and sealing material on the growth of seedling. The bars represent SEs, $\mathrm{n}=50$. 'P' or 'M' represents parafilm or Micropore ' $\mathrm{M}$ ' tape, respectively. 
Table 3. Effects of medium phase and supports on the growth of seedlings after $75 \mathrm{~d}$ of subculture.

\begin{tabular}{|c|c|c|c|c|c|c|c|c|c|c|c|}
\hline & \multicolumn{3}{|c|}{ Seedling growth (\%) } & \multicolumn{3}{|c|}{ Leaf length (mm) } & \multicolumn{2}{|r|}{ Root } & \multicolumn{3}{|c|}{ Plant wt } \\
\hline & 1 leaf & 2 leaves & 3 leaves & First & Second & Third & No. & Length (mm) & Fresh $(\mathrm{g})$ & Dry (g) & Dry/fresh (\%) \\
\hline$\overline{\mathrm{S}_{100}^{90} \mathrm{z}}$ & $43.2 \mathrm{a}^{\mathrm{x}}$ & $56.8 \mathrm{~b}$ & $0 \mathrm{c}$ & $6.7 \mathrm{~d}$ & $3.6 \mathrm{~d}$ & $0 \mathrm{c}$ & $1.0 \mathrm{~b}$ & $7.3 \mathrm{~b}$ & $1.19 \mathrm{c}$ & $0.06 \mathrm{c}$ & $5.0 \mathrm{~b}$ \\
\hline $\mathrm{LO}_{20}^{36 \mathrm{y}}$ & $0 \mathrm{c}$ & $21.6 \mathrm{c}$ & $78.4 \mathrm{a}$ & $12.8 \mathrm{a}$ & $9.2 \mathrm{a}$ & $8.6 \mathrm{a}$ & $1.0 \mathrm{~b}$ & $11.5 \mathrm{a}$ & $3.88 \mathrm{a}$ & $0.47 \mathrm{a}$ & $12.1 \mathrm{a}$ \\
\hline $\mathrm{LO}_{40}^{72}$ & $0 \mathrm{c}$ & $83.8 \mathrm{a}$ & $16.2 \mathrm{~b}$ & $7.4 \mathrm{bc}$ & $6.4 \mathrm{~b}$ & $4.5 \mathrm{~b}$ & $0.8 \mathrm{c}$ & $3.8 \mathrm{c}$ & $2.74 \mathrm{~b}$ & $0.30 \mathrm{~b}$ & $10.9 \mathrm{a}$ \\
\hline $\mathrm{LR}_{50}^{36}$ & $21.6 \mathrm{~b}$ & $78.4 \mathrm{a}$ & $0 \mathrm{c}$ & $8.6 \mathrm{~b}$ & $5.6 \mathrm{bc}$ & $0 \mathrm{c}$ & $1.2 \mathrm{a}$ & $11.6 \mathrm{a}$ & $2.51 \mathrm{~b}$ & $0.14 \mathrm{c}$ & $5.6 \mathrm{~b}$ \\
\hline $\mathrm{LN}_{40}^{36}$ & $43.2 \mathrm{a}$ & $56.8 \mathrm{~b}$ & $0 \mathrm{c}$ & $7.9 \mathrm{bc}$ & $5.0 \mathrm{c}$ & $0 \mathrm{c}$ & $1.0 \mathrm{~b}$ & $10.8 \mathrm{a}$ & $1.73 \mathrm{c}$ & $0.10 \mathrm{c}$ & $5.8 \mathrm{~b}$ \\
\hline
\end{tabular}

${ }^{\mathrm{z}}$ Medium phase $\mathrm{S}=$ solid; $\mathrm{L}=$ liquid; support $\mathrm{O}=$ without support; $\mathrm{R}=$ raft; $\mathrm{N}=$ nonwoven fabric covered with paper towel.

y Twenty milliliters of liquid media was added on the 45 th $\mathrm{d}$.

xDifferent letters within a column represent significant difference at $P \leq 0.05$ by Duncan's multiple range test.

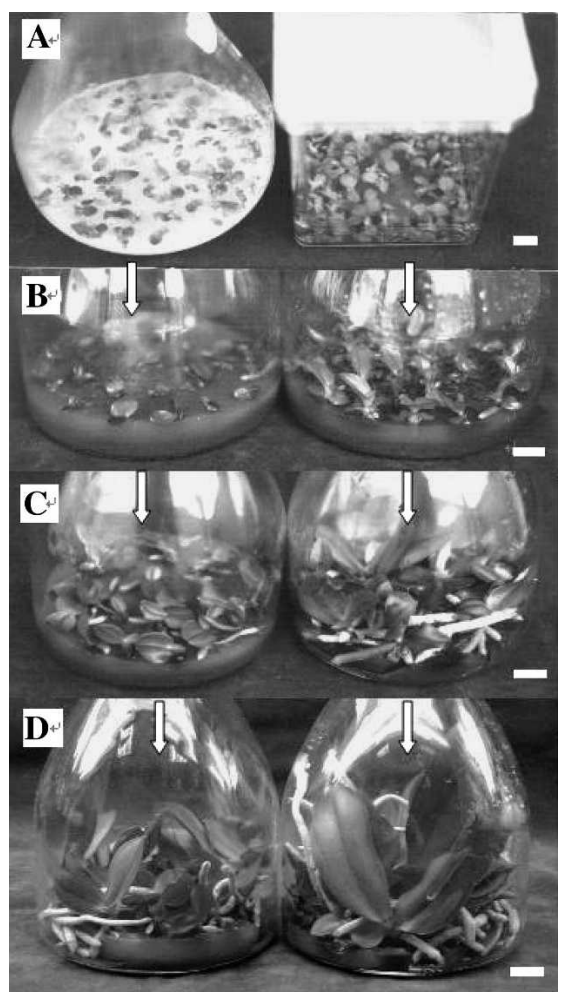

Fig. 4. Seedlings sown in liquid medium for 75 $\mathrm{d}$ were subcultured for $45 \mathrm{~d}$ on solid (A, left) or in liquid medium (A, right) and then transplanted to solid medium for $30(\mathbf{B}), 60(\mathbf{C})$ or 120 (D) d. $\operatorname{Bar}=10 \mathrm{~mm}$.

Table 4. Effects of culture method during subculture on the growth of seedlings after $120 \mathrm{~d}$ of pretransplanting.

\begin{tabular}{|c|c|c|c|c|}
\hline \multirow[b]{2}{*}{ Subculture $^{z}$} & \multicolumn{2}{|c|}{ Leaf } & \multicolumn{2}{|c|}{ Root } \\
\hline & No. & $\begin{array}{c}\text { Length } \\
(\mathrm{cm})\end{array}$ & No. & $\begin{array}{l}\text { Length } \\
(\mathrm{cm})^{\mathrm{x}}\end{array}$ \\
\hline $\mathrm{LO}_{20}^{36}$ & $5.3 \mathrm{a}^{\mathrm{y}}$ & $5.9 \mathrm{a}$ & $4.2 \mathrm{a}$ & $4.9 \mathrm{a}$ \\
\hline $\mathrm{S}_{100}^{90}$ & $4.2 \mathrm{~b}$ & $3.8 \mathrm{~b}$ & $3.7 \mathrm{a}$ & $4.5 \mathrm{a}$ \\
\hline
\end{tabular}

${ }^{\mathrm{z}}$ Medium phase $\mathrm{S}=$ solid; $\mathrm{L}=$ liquid; support $\mathrm{O}=$ without support; $\mathrm{R}=$ raft; $\mathrm{N}=$ nonwoven fabric covered with paper towel.

${ }^{y}$ Different letters within a column represent significant different at $P \leq 0.05$ by Duncan's multiple range test.

${ }^{\mathrm{x}}$ Longest root.

3 months (Table 1). After subculturing 75-dold seedlings in liquid medium for $45 \mathrm{~d}$, shoot growth was enhanced regardless of whether supports were used (Table 2), confirming that no hyperhydric seedlings occurred in liquid culture.

The desiccation or maturation drying of most seeds is the terminal phase of seed development leading to a metabolic quiescence state. Subsequent rehydration of mature dry seeds leads to germination, and hence the loss and gain of water play a role in the transition from a developmental program to a germination program (Dasgupta and Bewley, 1982). By desiccation, the zygotic embryo axis of Ricinus communis switched into the germination mode from the development mode by destroying certain mRNA and synthesizing new mRNA (Kermde and Bewley, 1985). Dramatic desiccation of vitreous protocorm-like bodies (PLBs) of Darwinana and Brassocattleya enhanced the number of regenerated plantlets. It was proposed that desiccation of PLBs must have induced a change in direction from enlargement and micropropagation of PLBs to develop leaves and roots (Kishi and Kakagi, 1997). Thus, the control of the liquid level for the desiccation of seedling turning from protocorm enlargement to meristem differentiation was important in liquid sowing. In our previous study, when Phalaenopsis seeds were sown on a support of nonwoven fabrics or a microporous membrane raft with $40 \mathrm{~mL}$ liquid medium in a GA-7 vessel, $20 \%$ or $30 \%$ of seedlings were hyperhydrated, respectively (Tsai and Chu, 2004). In this study, when $20 \mathrm{~mL}$ of medium was supplied and the petri dish was sealed with parafilm, medium desiccation resulted in seedlings protruding above the liquid level 7 weeks after sowing. Subsequently, $98.3 \%$ of seedlings developed normal leaves 3 months after sowing (Table 1).

Modification of medium had been used to control hyperhydricity such as increasing the concentration of gelling agent (Debergh, 1983; Marga et al., 1997; Pasqualetto et al., 1986), decreasing the concentration of cytokinin (Kataeva et al., 1991) or ammonium ions (Daguin and Letouzé, 1987), addition of antivitrification agents (Phan and Hegedus, 1986; Whitehouse et al., 2002) as well as inoculation with bacteria such as Pseudomonas sp. (Perry et al., 1999). Reducing the relative humidity in the culture vessel (Park et al., 2004), two-phase culture (Kadota et al., 2001; Viseur, 1987), and use of support (Takazawa and Kozai, 1992) are also reported effective in preventing hyperhydricity. However, it is an easy and economical way to enhance the normal and uniform growth of seedlings by accurately controlling the liquid level with medium volume and sealing materials shown in this study.

In conclusion, static sowing of $1.5 \mathrm{mg}$ Doritaenopsis seeds in $20 \mathrm{~mL}$ of liquid medium per $9-\mathrm{cm}$ petri dish sealed with parafilm for $75 \mathrm{~d}$ and subculturing 36 seedlings in $20 \mathrm{~mL}$ liquid medium without support are suggested for the fast and uniform growth of seedlings. It was expected that by liquid culture, the period from seed sowing to ex vitro could be 1.5 months shorter than the traditional solid culture.

\section{Literature Cited}

Arditti, J. 1992. Fundamentals of orchid biology. Wiley, NY.

Daguin, F. and R. Letouzé. 1987. Vitreous plants in vitro: Relationship with ammonium content of the nutrient medium. Acta Hort. 212: 259-261.

Dasgupta, J. and J.D. Bewley. 1982. Desiccation of axes of Phaseolus vulgaris during development causes a switch from a developmental pattern of protein synthesis to a germination pattern. Plant Physiol. 70:1224-1227.

Debergh, P. 1983. Effect of agar brand and concentration on the tissue culture medium. Physiol. Plant. 59:270-276.

Douglas, G.C. 1984. Propagation of eight cultivars of Rhododendron in vitro using agar-solidified and liquid media and direct rooting of shoots in vivo. Sci. Hort. 24:337-347.

Edwin, F.G. 1993. Plant propagation by tissue culture. Exegetics Ltd., Edington Wilts, UK.

Etienne, H. and M. Berthouly. 2002. Temporary immersion systems in plant micropropagation. Plant Cell Tissue Organ Cult. 69:215-231.

Kadota, M., K. Imizu, and T. Hirano. 2001 Double-phase in vitro culture using sorbitol increases shoot proliferation and reduces hyperhydricity in Japanese pear. Sci. Hort. 89: 207-215.

Kataeva, N.V., I.G. Alexandrova, R.G. Butenko, and E.V. Dragavtceva. 1991. Effect of applied and internal hormones on vitrification and apical necrosis of different plants cultured in vitro. Plant Cell Tissue Organ Cult. 27:149-154.

Kermde, A.R. and J.D. Bewley. 1985. The role of maturation drying in the transition from seed development to germination. 1. Acquisition of desiccation-tolerance and germinability during development of Ricinus communis $L$. seeds. J. Expt. Bot. 36:1906-1915.

Kim, E.K., E.J. Hahn, H.N. Murthy, and K.Y. Paek. 2003. High frequency of shoot multiplication and blublet formation of garlic in liquid cultures. Plant Cell Tissue Organ Cult. 73: 231-236. 
Kishi, F. and K. Kakagi. 1997. Efficient method for the preservation and regeneration of orchid protocorm-like bodies. Sci. Hort. 68:149-156.

Knudson, L. 1946. A new nutrient solution for the germination of orchid seeds. Amer. Orchid Soc. Bul. 15:214-217.

Lee, N. 1990. Embryo culture of orchids. J. Chinese Soc. Hort. Sci. 36:223-244.

Marga, F., L. Vebret, and H. Morvan. 1997. Agar fractions could protect apple shoots cultured in liquid media against hyperhydricity. Plant Cell Tissue Organ Cult. 49:1-5.

Murashige, T. and F. Skoog. 1962. A revised medium for rapid growth and bioassay with tobacco tissue culture. Physiol. Plant. 15:473-497.

Park, S.W., J.H. Jeon, H.S. Kim, Y.M. Park, C. Aswath, and J. Joung. 2004. Effect of sealed and vented gaseous microenvironments on the hyperhydricity of potato shoots in vitro. Sci. Hort. 99:199-205.

Pâques, M., J. Bercetche, and E. Dumas. 1992. Liquid media to improve and reduce the cost of in vitro conifer propagation. Acta Hort. 319:95-100.
Pâques, M. and Ph. Boxus. 1987. 'Vitrification': Review of literature. Acta Hort. 212:155166.

Pasqualetto, P., R.H. Zimmerman, and I. Frodham. 1986. Gelling agent and growth regulator effects on vitrificaation of 'Gala' apple in vitro. J. Amer. Soc. Hort. Sci. 111:976-980.

Perry, P.L., K. Ueno, and K. Shetty. 1999. Reversion to hyperhydration by addition of antibiotics to remove Pseudomonas in unhyperhydrated oregano tissue cultures. Process Biochem. 34:717-723.

Phan, C.T. and P. Hegedus. 1986. Possible metabolic basis for the developmental anomaly observed in in vitro culture, called 'vitreous plants'. Plant Cell Tissue Organ Cult. 6:8394.

Takazawa, A. and T. Kozai. 1992. Effects of types of culture vessel with supporting materials on the growth of carnation plantlets in vitro. Environ. Control Biol. 30:394-396.

Tsai, W.T. and C.Y. Chu. 2004. Effect of support on the growth of Phalaenopsis seedlings in vitro. Hort. Natl. Chung Hsing Univ. 29:85-97.
Viseur, J. 1987. Micropropagation of pear, Pyrus communis L., in a double-phase culture medium. Acta Hort. 212:117-124.

Whitehouse, A.B., R.M. Timothy, and A.E. Glyn. 2002. Control of hyperhydricity in Eucalytpus axillary shoot cultures grown in liquid medium. Plant Cell Tissue Organ Cult. 71: 245-252.

Wong, M.Y. and C.Y. Chu. 1995. Effect of medium phase on the growth of rose explants in vitro. J. Agr. For. 44:71-77.

Yoder, J.A., L.W. Zettler, and S.L. Stewart. 2000. Water requirements of terrestrial and epiphytic orchid seeds and seedlings, and evidence for water uptake by means of mycotrophy. Plant Sci. 156:145-150.

Zhou, T.S. 1995. In vitro culture of Doritaenopsis: Comparison between formation of the hyperhydric protocorm-like-body (PLB) and the normal PLB. Plant Cell Rpt. 15:181185.

Ziv, M. 1994. Quality of micropropagated plants - Vitrification. In Vitro Cell. Dev. Biol. Plant 27:64-69. 